\title{
Disaster Medicine and Wartorn Former Yugoslavia
}

\author{
Peter Safar, MD, Drhc, FCCM
}

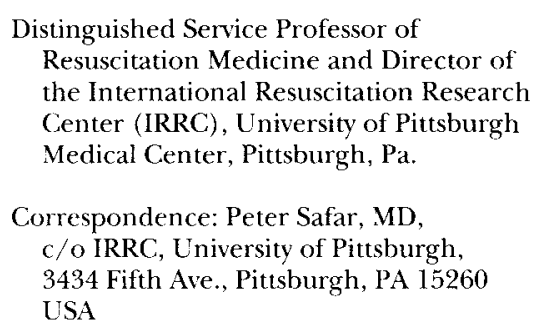

Distinguished Service Professor of Resuscitation Medicine and Director of the International Resuscitation Research Center (IRRC), University of Pittsburgh Medical Center, Pittsburgh, $\mathbf{P a}$.

Correspondence: Peter Safar, MD, c/o IRRC, University of Pittsburgh, 3434 Fifth Ave, Pittsburgh, PA 15260 USA

Keywords: Balkans; Bosnia; civil war; disasters; emergency medical services; Herzegovina; killing; life-supporting first-aid; Sarajevo

\author{
Abbreviations: EMS = emergency \\ medical services; IRRC = International \\ Resuscitation Research Center; \\ LSFA = life-supporting first-aid; \\ WADEM $=$ World Association for \\ Disaster and Emergency Medicine
}

Sarajevo, the capital of Bosnia and Herzegovina, with a pre-war population of 550,000 , has been under siege since April 1992. So far, more than 10,000 people in the city have been killed (including 1,500 children), and more than 50,000 people have been wounded (including 15,000 younger than age 18 years). ${ }^{1}$ Sarajevo's largest hospital, the Kosevo University Hospital (with approximately 2,000 beds), has been shelled systematically and hit more than 200 times. Fifteen staff members have been killed inside the hospital's complex. Physicians from the State Hospital of Sarajevo (with about 200 beds) report on the emergency care of civilians in wartorn Sarajevo in the special supplement to this issue of Prehospital and Disaster Medicine. They have done this as objectively as possible under the unbearable circumstances of the siege, considering that attempts to save one's own and others' lives has priority over data recording.

The past and present conflicts underlying the recent brutal war in the Balkans, which began in spring 1991 between Serbian and Croatian forces, remain exceedingly complex and are beyond the scope of this journal. However, the medical dictum that prevention is preferred before the need for treatment arises also applies to wars. The many opportunities since the death of former Yugoslavian President Tito in 1980 to prevent this tragedy were missed by the people of Yugoslavia and by international leaders.

Ernesto Pretto, MD, of the International Resuscitation Research Center (IRRC) at the University of Pittsburgh, who in 1990 was delegated the leadership of the disaster reanimatology research program, decided to extend his research on mass disasters beyond the effects of earthquakes and to learn about humanmade mass disasters as well. In May 1993, he visited-with difficulty and risks-the besieged city of Sarajevo, on a humanitarian and fact-finding mission and to deliver donated equipment used for rapid transfusion and blood cell salvage. ${ }^{2}$ He asked me to comment on the situation in the former Yugoslavia because I have been familiar with that country since the $1930 \mathrm{~s}$ and have striven during the 1990 s, through the World Federalists and United Nations Associations of the United States, and the academies of sciences of Slovenia, Austria, and Germany (of which I am a member), to help stop the killing and maiming of civilians through pressure on politicians.

Such efforts have helped arouse public conscience, but so far have been unsuccessful in bringing peace. Physicians, most of whom by professional commitment and oath (in my opinion), should be pacifists, now find themselves in a dilemma. It may be too late to stop the ongoing murdering, maiming, raping, dispossessing, and expulsion of innocent people without resorting to the credible threat of (and willingness to use) an overwhelming military force. So far, neither the United States, nor European governments, nor the United Nations Security Council, has exerted sufficient force to stop the genocide. Such a force must apprehend and punish the aggressors. The European and United States governments have been unwilling to use such force, in part, because they fear that it would kill allied soldiers and additional civilians.

How can we, as health professionals, just apply Band-Aids and count the dead and injured while ignoring the cause of the disease? Even in peacetime during the nineteenth century in Europe, some pioneers of modern medicine such as Virchow of Berlin and Billroth of Vienna considered medicine to be partially a social science and political activism to be a necessary therapeutic tool. In conflicts like the one presently going on in the for- 
mer Yugoslavia, which include war crimes, the separation of political and medical considerations is impossible and would be hypocritical. Bringing medical supplies into encircled, bombarded Sarajevo is necessary and laudable. One must admit, however, that it represents merely a modest palliative effort. It is not specific, effective therapy, as would be stopping those who do the killing.

The culprits are not the majority of Serbs and Croats inside or outside the original territory of Bosnia and Herzegovina. Most of the people of former Yugoslavia, people of diverse ethnic and religious backgrounds, are good people. The fraternicide and genocide that are destroying the formerly secular, peaceful, multiethnic, multireligious, and culturally tolerant society of Bosnia and Herzegovina are being perpetrated from the outside, by a few power-hungry and fanatic nationalists consisting mostly of former communists. They are inhumane leaders, who have brainwashed and forced others to be hateful collaborators. These leaders and their followers are military thugs, who label themselves as "Chetniks" of Serbia and "Ustashas" of Croatia. These historic elite killers are comparable to Hitler's SS. Physicians who go beyond traumatology will find the study of these facts interesting from historic and psychologic-psychiatric viewpoints.

The conditions that Dr. Pretto encountered in Sarajevo have been challenging improvisations in emergency care for more than one year, in ways not previously experienced during international and civil wars. The physicians, nurses, and other health care workers of Sarajevo are competent, advanced professionals. Medicine in Sarajevo was of a high caliber, like that found in the German-speaking countries to the north. The poor medical conditions currently found there are different from those encountered in Third World countries. Now, civilians, including health care workers, are trapped and exposed daily to brutalities, including being the targets of snipers and shells from the surrounding hills.

Disaster reanimatology is a term introduced by us in 1976 at the initiation of the Club of Mainz, now called the World Association for Disaster and Emergency Medicine (WADEM) ${ }^{3}$ This term is borrowed from Negovsky's reanimatology. Those of us in the field of disaster reanimatology again are learning from the tragic events in the Balkans that each disaster, human-made or natural, must be treated as a separate disease. In Sarajevo, the emergency medical services (EMS), which were in place before the war, have been decimated. Help from the surrounding EMS systems is denied by the aggressors. The surrounding countryside is entirely under the control of the Serbian or Croatian military. International medical help from the outside, only possible by air, is limited because access from the airport into Sarajevo, even the area under United Nations "protection," is controlled by the aggressors. ${ }^{2}$

Life-supporting first-aid (LSFA) by those who are uninjured remains the first, most important step in the life support chain. ${ }^{4}$ Attempts by bystanders to deliver LSFA, however, can be highly life-threatening, not only for military paramedics, but for all citizens. Day and night, a variable number of severely injured people receive LSFA by civilians, despite the great personal risk. In unprotected areas, these Good Samaritans often are fired on, and many have been hit. This was demonstrated on the videotape brought back by Dr. Pretto. It showed rescue efforts during the "breadline massacre" of 27 May 1992, and sniper fire hitting already injured citizens on the street. Usually, there is no time for stabilization in the field, and people have to use the "scoop and run" approach trying to "resuscitate while running." Health professionals have been selectively and specifically targeted while on duty. In the hospitals of Sarajevo, even special care units have been targeted deliberately by tank gunners and snipers. In hospitals, staffs have been working for months, often with no electricity, no heat, no running water, poor sanitation, and often with exhausted supplies, including anesthetics and oxygen. The articles in the supplement illustrate traumatologic resuscitation, anesthesia, surgery, and life support under "primitive," improvised conditions by personnel with modern medical education.

The IRRC's multidisciplinary disaster research program focuses on reanimatology. ${ }^{3}$ It focuses on those who are not killed immediately, but those who die slowly after a disaster strikes, and in whom special application of modem resuscitation methods sometimes might lead to survival without major disability. Considerable information on resuscitation potentials in acute mass disasters recently has come from retrospective interview studies of major earthquakes. ${ }^{4}$ Earthquakes are sudden impact events that are followed by rescue, resuscitation, and rehabilitation. This type of natural mass disaster has served as a model "disease" for research. The results hopefully will influence planning and preparedness and improve future responses. The situation in Sarajevo and other populated areas in Bosnia and Herzegovina that are isolated and under chronic bombardment and sniper fire is quite different. Sarajevo and other enclaves under siege are suffering from the chronic civilian disaster of ongoing trauma and deprivation. The situation in. Sarajevo also differs from the challenges ordinarily met by military medicine, which is designed to provide care for wounded soldiers. Military medical personnel usually are well-equipped and have some form of an organized life-support chain, including transport and evacuation. In this war, however, $80 \%$ of casualties have been civilians, supplies are exhausted, and transport and evacuation of the wounded are nearly impossible to achieve.

The 380,000 citizens of Sarajevo who remain there, people of all ethnic and religious backgrounds, are in their second winter of life-threatening deprivations. The aggressors are attempting to stop deliveries of water, food, gas, oil, electricity, and medical supplies. The captives are waiting for the final onslaught in which the Chetniks' tanks will try to take the city. That could result in mass murder and possibly even annihilation of the population, resembling what happened in the Warsaw ghetto during World War II. The citizens are losing hope of being liberated, as was the case for those in the besieged citadel of Leningrad in World War II.

The lessons of emergency care learned from Sarajevo, 
Mostar, and other besieged communities in Bosnia and Herzegovina teach military and civilian reanimatologists the following: 1) methods, priorities, and improvisations for providing acute medical care under chronic adverse conditions with minimal equipment and lack of supplies; 2) methods of medical preparedness and long-term supplies needed in the chronic disasters of civil wars; and 3) about man's inhumanity to man in the form of war crimes. Health professionals have an opportunity to document these crimes and to bring them before the present ad-hoc "International War Crimes Tribunal of the
United Nations," and later before the still-to-be-established, permanent "International Criminal Court." Prosecution to justice would help to prevent a recurrence of this lethal disease. As the International Physicians for the Prevention of Nuclear War helped stop the nuclear arms confrontation between the Superpowers (and received the Nobel Peace Prize of 1985), so can reanimatologists help achieve "world peace through world law." Activism by humanists might justify optimism that the chronic disaster of Sarajevo will end soon, and will not repeat itself in a world that is seeking a new order.

\section{References}

1. Mission of the Republic of Bosnia-Herzegovina to the United Nations, New York City: Press release of 13 December 1993.

2. Pretto EA, Begovic M, Begovic M: Emergency medical services during the siege of Sarajevo, Bosnia and Herzegovina: A preliminary . report. Prehospital and Disaster Medicine 1994;9:s39-s45.
3. Safar P: Resuscitation potentials in mass disasters. Prehospital and Disaster Medicine 1986;2:34-47.

4. Pretto EA, Ricci E, Klain M, et al: Disaster reanimatology potentials: A structured interview study in Armenia III. Results, conclusions, and recommendations. Prehospital and Disaster Medicine 1992; 7:327-338.

\section{Editorial Comment}

Since December 1993, when this editorial was written, a show of force by the United Nations and NATO has resulted in the Serbs removing their big guns from Sarajevo's suburbs and reducing the violence. However, killing is continuing in other parts of Bosnia. Most promising, in March 1994, U.S. mediation has led to peacemaking between the governments of Bosnia and Croatia. If and when the government of Serbia does the same, and when a secure peace has been established, an enormous task lies ahead for international aid to help our colleagues in former Yugoslavia rebuild their medical infrastructure. Until all guns are silent, however, peacemaking efforts should not ignore the desperate needs for medical supplies and food. In order to save innocent lives, medical supplies and food will have to be delivered, when necessary, by a show of force against the murderers.-Peter Safar, MD, Drhc, FCCM 


\title{
Emergency Gardiac Gare Update
}

\author{
May 12-15, $1994 \bullet$ Richmond, Virginia
}

Who attends? CPR and ACLS instructors $\bullet$ Cardiac researchers Physicians $\bullet$ EMS providers $\bullet$ Dispatchers $\bullet$ Industrial safety officers Nurses $\bullet$ Public education and information officers

The last ECCU Conference brought over 1,000 people to Seattle-an exciting, history-making event participants still talk about. Attendees came from more than two dozen countries.

Join us in Richmond to learn the future of CPR and emergency cardiac care-an international conference that will prepare you to meet the heady challenges we all face.

\section{Special for instructors...}

This is the source for the most up-to-date CPR training standards and news, internationally. Please join us!

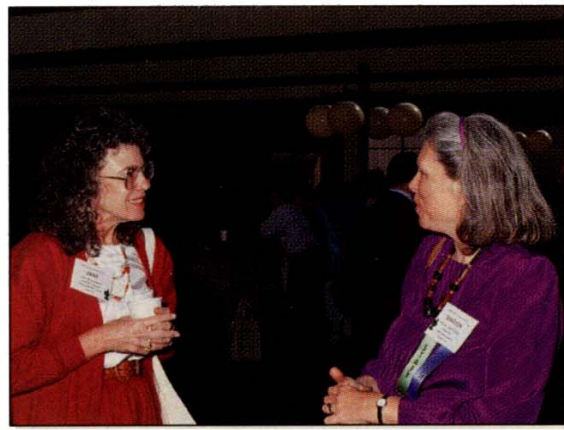

Network...recharge...rub shoulders with professionals like you who want to be on the vanguard of change in CPR and ECC... BE THERE!
PLUS...

- Talk one-on-one with the experts - and your peers

- Find out how to customize the chain of survival for your community

- Get the latest news about the new EMT curriculum and ACLS course

- Take back solid, practical ideas to put to work right away 
Let us give you a hand addressing the new American Heart

\section{Association guidelines}

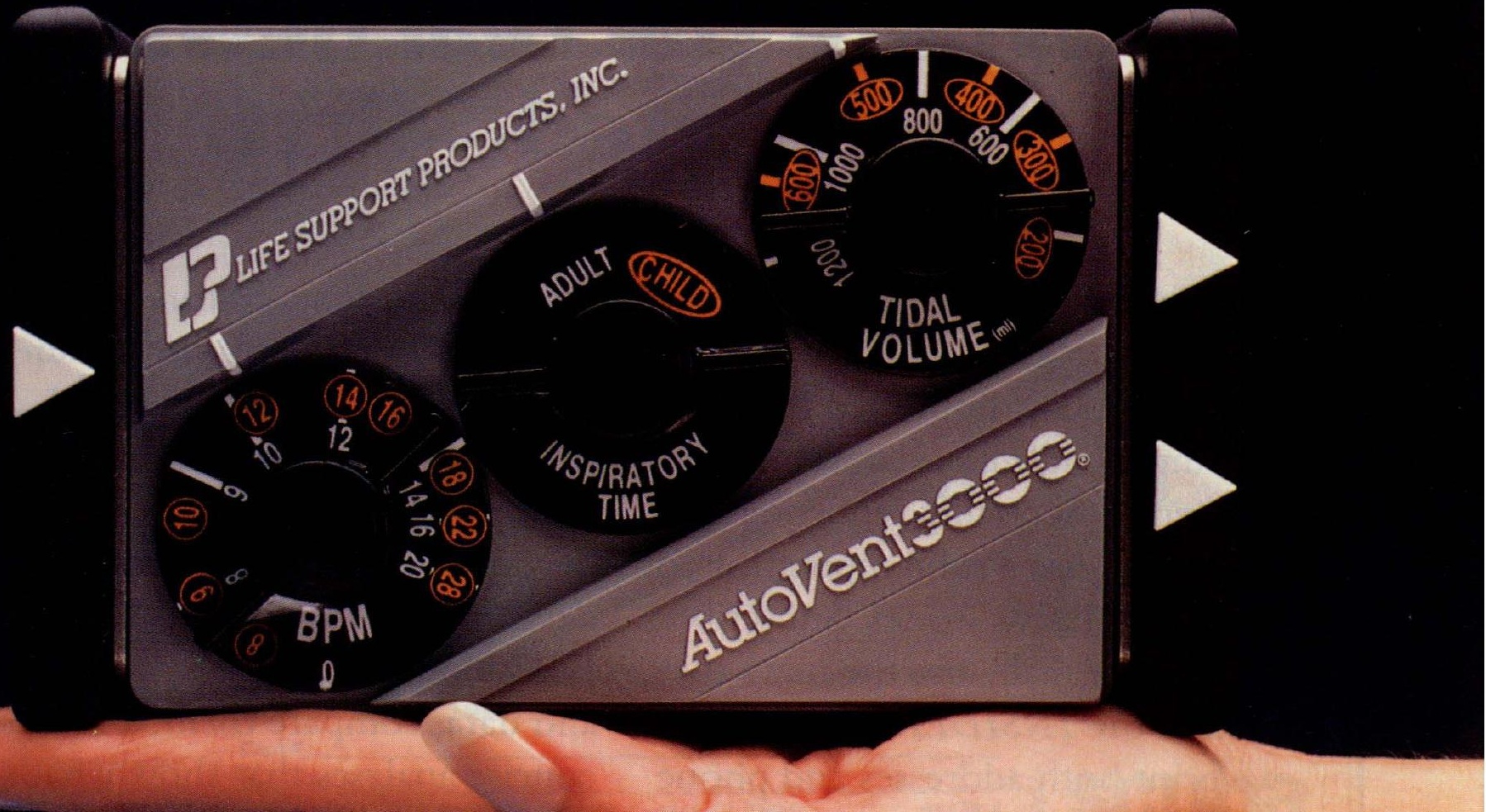

If you would like to learn more about how the LSP AutoVent 2000 or AutoVent 3000 can help you save time and money, improve patient care and address the new AHA guidelines - simply contact us at 1-800-225-4577 for the nearest LSP Distributor.

And don't forget to ask your LSP Distributor for a copy of the new video "Prehospital Ventilation - Issues and Answers."

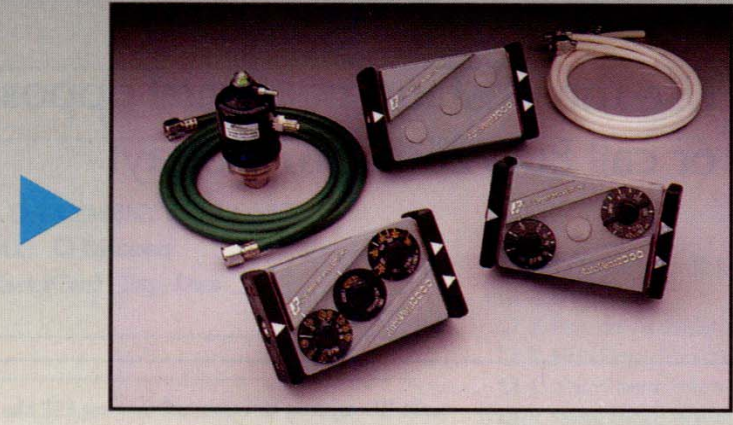

The ISpl AutoVent Series
S

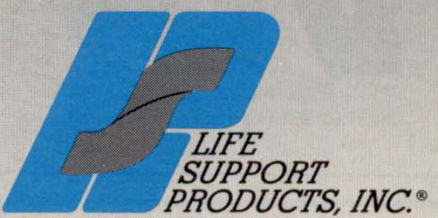

One Mauchly, Irvine, CA 92718 


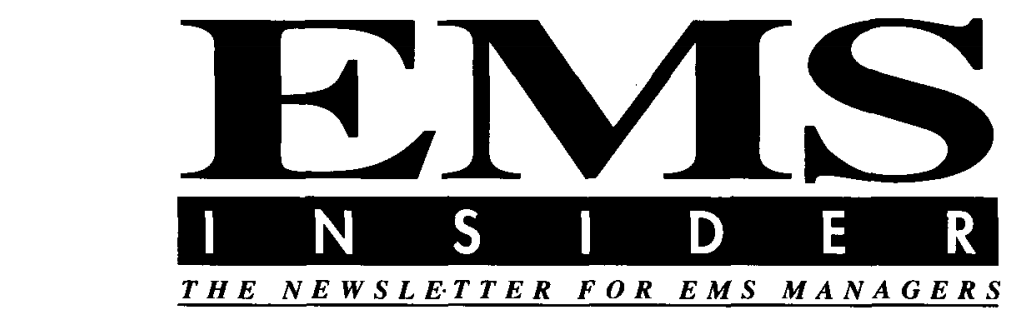

\section{Where the real news is reported-first.}

The EMS INSIDER is the finest source of concentrated EMS news available today. Published by Jems Communications and backed by an insistence on quality reporting, the INSIDER has a solid reputation for timely, exclusive stories. Subscribers tell us they really use the news they read in the INSIDER (which is why we print both addresses and phone numbers of key contacts at the end of articles).

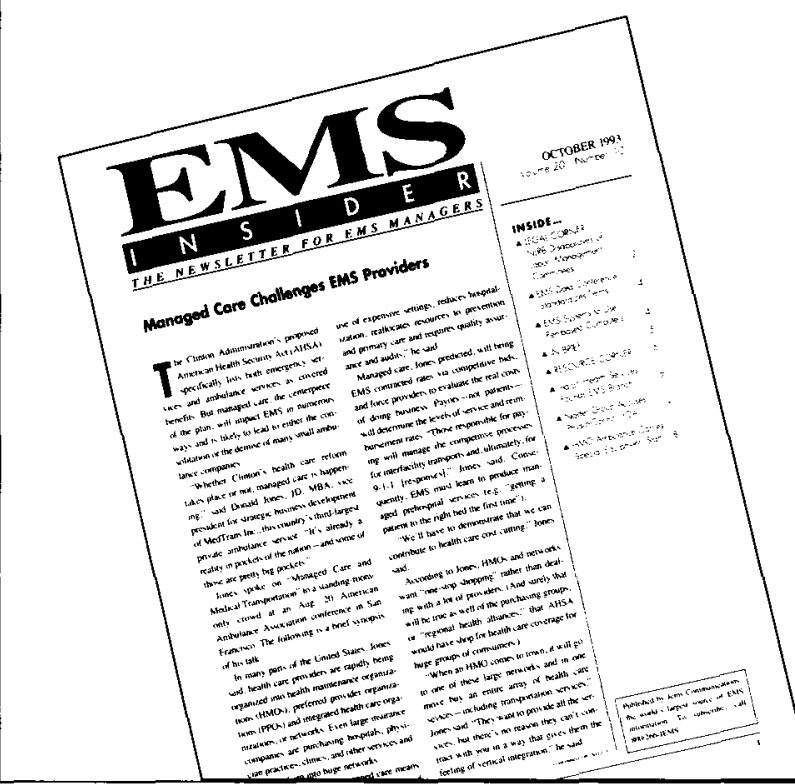

Every week, Jems editors scour hundreds of publications, make dozens of phone calls and read reports from all over the country to get the scoop on legal decisions, new government regulations, late developments and trends in the EMS industry. We take raw facts and data, compare them, and create concise analyses that show what's really happening in EMS.

Wouldn't you like to receive the best inside information - every month-without spending your own precious time compiling it? Now you can.

Subscribe to the EMS INSIDER. Get the time-sensitive news you can act on with confidence.

Use the postage-paid card opposite or call $800 / 266-5367$, today! 
ARIZONA - EMS Physician/Fellowship Director/Director of EMS Education.

The University of Arizona is seeking a physician who is board certified or prepared in Emergency Medicine and has Fellowship training or equivalent EMS experience to join the faculty at the University of Arizona College of Medicine in Tucson. This position will be based within the Section of Emergency Medicine. The full-time faculty physician will serve as a staff attending in the University Medical Center emergency department. The faculty member should hold an interest in the education of EMT's, paramedics, medical students and EM house officers and will have the responsibility for coordinating the EMS fellowship program and resident education in EMS. The faculty member will serve as director of the training division of the Arizona Emergency Medicine Research Center. The faculty member will have the opportunity to develop a research focus within the area of EMS. The University of Arizona is an EOE/AA employer. Women and minorities are urged to apply.

Please write, call or fax Daniel W. Spaite, MD, Chairman, Search Committee, Section of Emergency Medicine, 1501 N. Campbell Ave., Tucson, AZ 85724; 602/626-6312, Fax 602/626-2480.

\section{Rates for classifieds:}

$\$ 55$ for 60 words or less and $\$ 2$ for each additional word

(or)

Please fax or mail your ad to:

Prehospital and Disaster Medicine

$\$ 45$ per column inch for display (includes photo, illustration, or logo)
Att: Classified Manager

P.O. Box 2789

Carlsbad, CA 92018
Fax: $619 / 431-8176$

\section{SAM Splint \\ THE POCKET CAST TM}

From the Himalayan Peaks to the depths of the ocean the SAM ${ }^{\circledR}$ Splint has proven itself effective and reliable.

Only $4 \% 2 " \times 36$ " and weighing 4 ozs. the SAM $^{\oplus}$ Splint is:

- foam padded for comfort

- adaptable for use

- invisible on x-rays

- waterproof

- reusable

- not affected by extremes in temperature or altitude

\section{SAM ${ }^{\otimes}$ Splint} THE POCKIET CAST TM Manufactured by:

The Seaberg Company, Inc.

P.O. Box 734 South Beach, OR 97366 Tel: (503) 867-4726 Fax: (503) 867-4646 U.S. Patent No. 3,843,923 and 4,678,233 Cannedien Patert No. 10,45,488 Other U.S. and Foreign Fatents Pending SAMe Sphint is a U.S. Registered Tradenat of

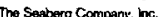

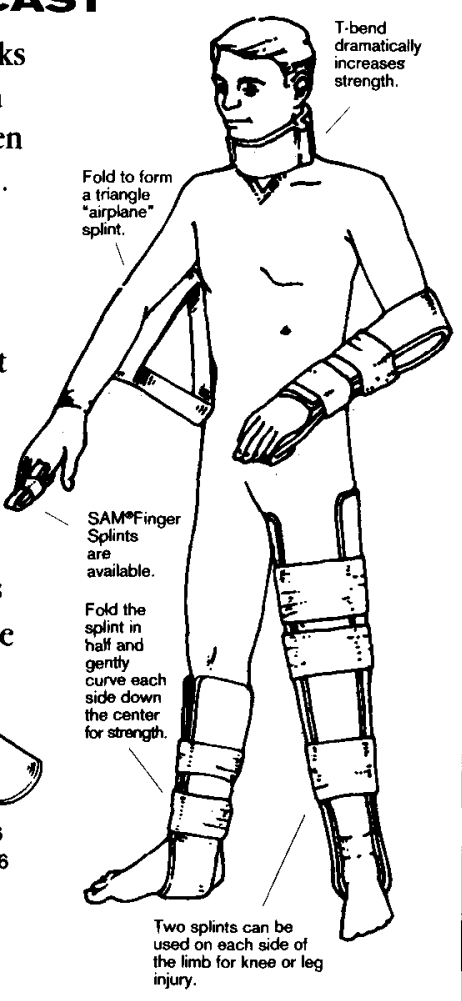

\section{Do you know how to treat a scuba diving accident? Does your staff?}

Chances are good that you've heard of the bends, but do you really know how to treat them?

Would you be confident knowing your EMS was responding to the scene of a scuba diving accident?

Divers Alert Network is an international nonprofit member-supported diving safety organization based at Duke University Medical Center.

DAN offers specialized information and training in diving medicine for divers and healthcare professionals. DAN helps EMS and physicians evaluate and treat diving-related injuries situations your EMS may face.
- DAN is supported by an international network of hyperbaric facilities and diving specialists.

- Since 1980, DAN has assisted over 60,000 divers who needed help.

- It is estimated there are over three million active scuba divers in the United States.

- Scuba diving takes place in every state wherever there's water, you're sure to find scuba divers.

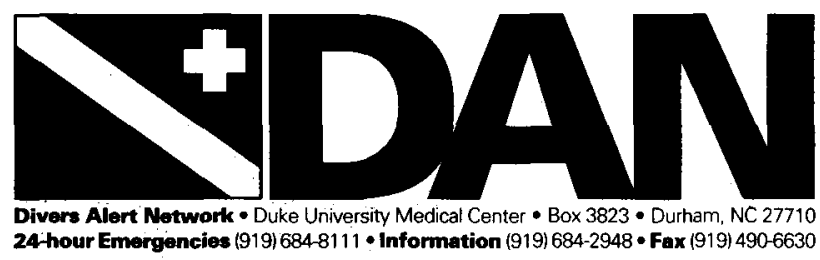




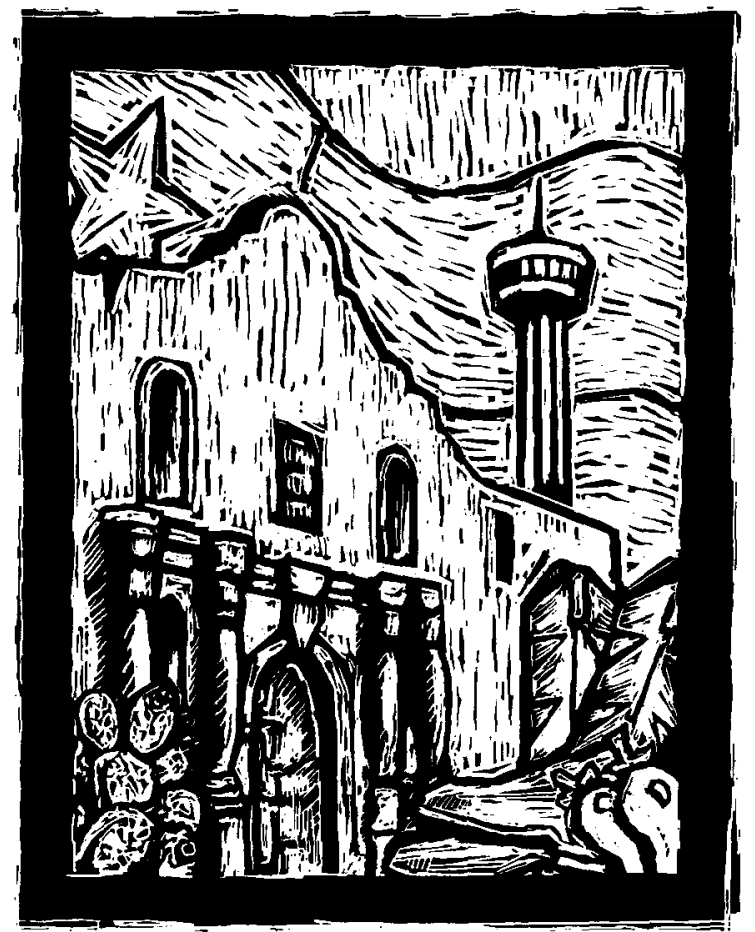

\section{Mark your calendars now for the Emergency Nurses Association's (ENA) Scientific Assembly}

\section{San Antonio, Texas \\ September 30 - October 2, 1994}

- Over $140 \mathrm{CECH}$-approved course offerings

- Topics covering: Leadership/Management,

Education, Research, Clinical, and Professional Issues

- Over 350 exhibitors in the Emergency Health

Care Products \& Services Education Center

- Network with over 2,600 emergency nurses

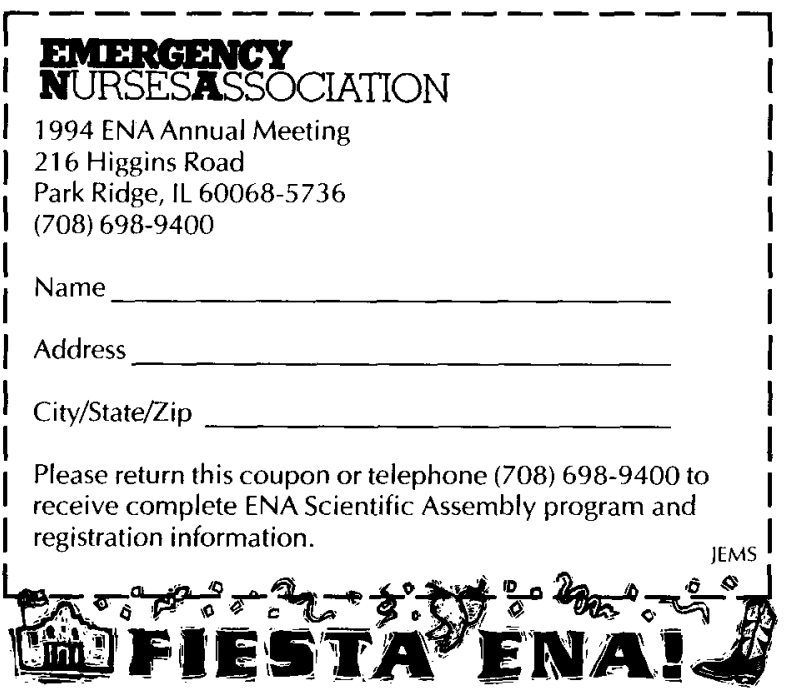

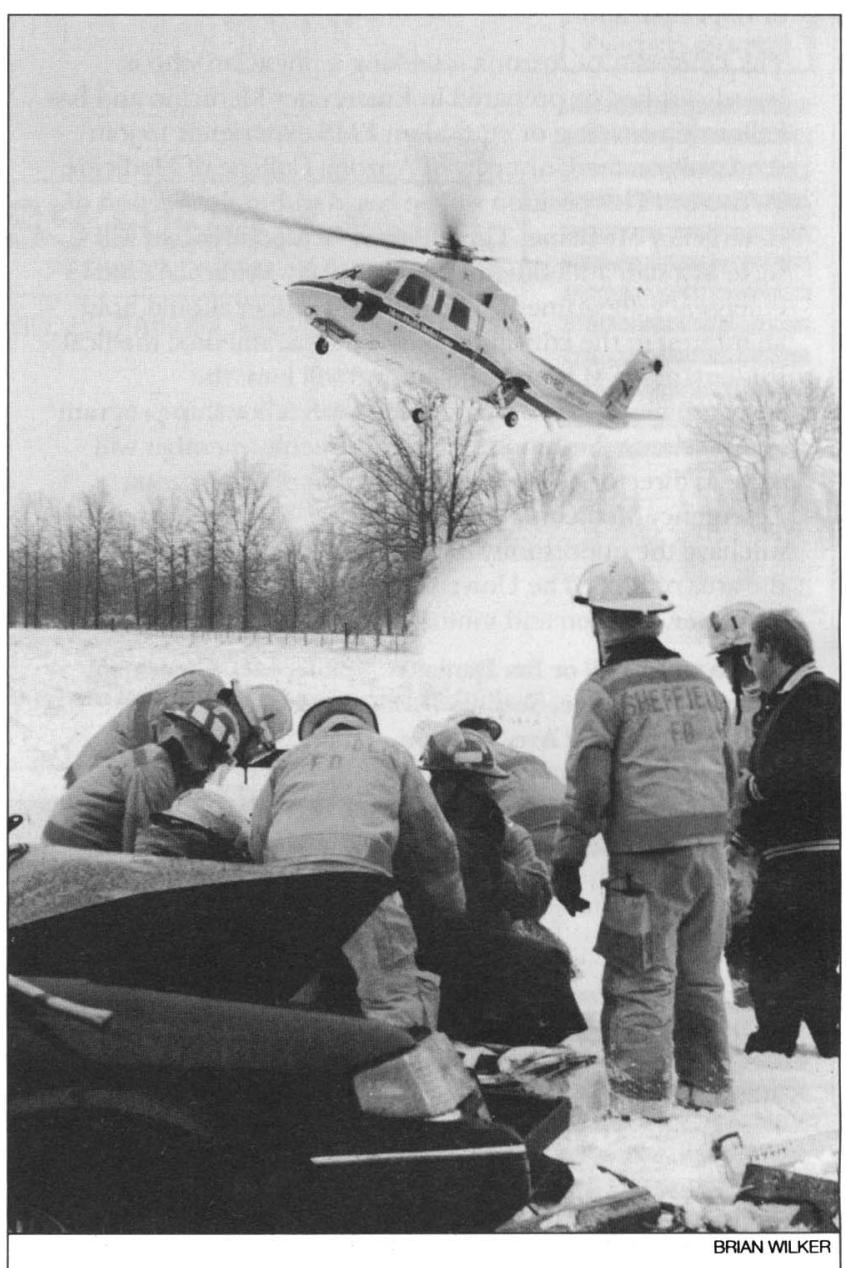

Air medical transport represents two important scientific arenas: medicine and aeronautics. Your patients depend on both when their critical condition calls for such transport. Shouldn't you keep yourself apprised of the latest developments in both fields? By reading Air Medical Journal you get the information you need to provide advanced life support through the use of air transport. Every month.

\begin{abstract}
Air Medical Journal.
The only journal dedicated solely to air medical transport. To subscribe for a full year (11 issues for just $\$ 30$ ) call 800/266-5367.
\end{abstract}

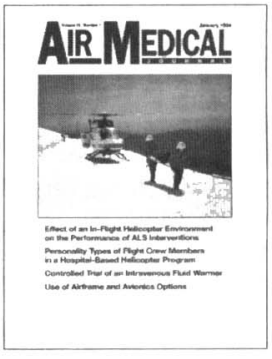

Air Medical Journal is the official publication of the Association of Air Medical Services (AAMS), the National Flight Nurses Association (NFNA), the National Flight Paramedics Association (NFPA) and the National EMS Pilots Association (NEMSPA).

\section{AIRMEDICAL}

